\title{
SÍNTESE CRÍTICO-REFLEXIVA DO PROFESSOR DE ESPANHOL NO ENSINO MÉDIO
}

\section{Autor: Lucas Amâncio Mateus ${ }^{1}$}

A presente análise baseia-se na obra Didática da Língua Espanhola no Ensino Médio, elaborada por Lígia Paula Couto, com o objetivo de discorrer sobre a ascensão da língua espanhola no ensino de línguas estrangeiras no Brasil, fazendo uma análise sobre a didática utilizada e suas aplicabilidades. Divide-se em duas partes que serão tratadas separadamente aqui.

O primeiro capítulo da primeira parte trata justamente dessa abordagem metodológica no ensino da Língua Espanhola, tratando dos princípios pedagógicos e didáticos. Demonstra-se a necessidade de aprofundar os debates sobre a orientação da prática docente, em que há notadamente a necessidade de uma reflexão por parte dos professores sobre a importância dos métodos e abordagens, estimulando um pensamento crítico a respeito desses, considerando sempre os objetivos de cada contexto de aprendizagem.

O capítulo 2 explora mais especificamente a presença da Língua Espanhola no Ensino Médio brasileiro, abordando incialmente seu histórico para, assim, tratar sobre os conceitos de língua e a importância de sua aprendizagem para o aluno dessa categoria. Destacando conceitos como os de gênero discursivo e de cultura, que são peças fundamentais no ensino da língua. $\mathrm{O}$ primeiro, visto como o conteúdo fundamental responsável por pautar a organização do planejamento, assim como as temáticas de interesse do aluno. O segundo, por sua vez, determina o contexto real dos alunos, e por isso precisa ser inserido como conteúdo.

O terceiro capítulo aprofunda a ideia da cultura - ou aspectos culturais - como conteúdo nas aulas de LE, demonstrando sua importância no processo de ensino e aprendizagem. Destaca a influência da diversidade cultural, e o cuidado que se deve ter em não selecionar aspectos considerados “melhores" culturalmente para serem abordados, em detrimento de outros de igual

\footnotetext{
${ }^{\text {I }}$ Mestrando em Estudos Linguísticos pela Universidade Federal de Uberlândia. Graduado em Administração pela mesma universidade e Licenciado em Letras Português/Inglês pela Universidade de Franca. Lattes: http://lattes.cnpq.br/oroiro2792314230. E-mail: lucasamanciomateus@gmail.com.
} 
importância. Ou seja, abordar aspectos culturais vai além de festas populares, comidas típicas e roupas tradicionais dos falantes da língua nas aulas, requer questões culturais que exercem importância para entender determinado povo e aproximar-se desses, sobrepondo-se a preconceitos culturais, e aproximando-se de suas identidades culturais.

Entrando para a segunda parte do livro - uma parte mais prática da análise - o primeiro capítulo dessa sessão trata sobre a presença dos gêneros discursivos em sala de aula e a maneira como podem contribuir para os processos de ensino-aprendizagem do espanhol, dando exemplos de exercícios e atividades que podem ser utilizados para atingir os objetivos propostos, destacando a importância para a seleção dos textos utilizados, considerando o interesse dos alunos e as necessidades de aprendizagem, assim como a variedade dos gêneros e a variedade dos países hispanófonos.

O segundo capítulo discorre sobre a cultura, tratando sobre as identidades culturais e as aulas de espanhol, em que se destaca o fato de que os conceitos de variação linguística e de identidade, possibilitam uma perspectiva mais abrangente da língua, a qual incorpora a cultura como seu elemento constituinte.

O terceiro capítulo explora as maneiras de introduzir a literatura nas aulas de língua

espanhola no Ensino Médio, explicitando os documentos oficiais que regem essa aplicação, assim como os aspectos que precisam ser considerados para tratar a literatura em LE, como por exemplo, a diversidade nas manifestações literárias, uma vez que essa língua é falada em mais de zo países. Trazendo exemplos de roteiros a serem utilizados, demonstra a importância de demonstrar os caminhos da literatura, como fomentadores do desenvolvimento de habilidades.

O quarto capítulo trata das habilidades de falar, ler, escrever e ouvir, que são denominadas como as "quatro habilidades" para a aquisição completa da língua, sendo consideradas como habilidades ativas (escrita e oralidade) e habilidades passivas (leitura e escuta). Com a mudança de conceitos através da evolução, deixa de se distinguir essas habilidades e passam a ser adotadas como todas as habilidades que requerem a participação do aluno, sendo a leitura e a escuta focadas na compreensão e a escrita e oralidades focadas na expressão.

No quinto capítulo, temos o entendimento de que, mesmo em um ensino com foco nos gêneros discursivos, a gramática não pode - nem deve - ser excluída dos processos de ensino da LE. Por isso, aponta algumas possibilidades de trabalho desse instrumento, sem que um cause o detrimento do outro.

Dentro desse contexto de se trabalhar por maneiras completas, diferentes e inovadoras, 
não poderia ficar de fora a abordagem sobre as formas de avaliação e sua aplicação dentro desse contexto defendido. Por isso, o capítulo 6 vem tratar sobre os processos de avaliação dentro desse contexto de ensino, destacando dois tipos de avaliações: diagnóstica e somativa, explicitando que, se bem utilizadas, contribuem para a aprendizagem dos alunos de maneira efetiva e individual, avaliando cada aluno a seu tempo e de acordo com suas habilidades.

Fechando a discussão proposta, o capítulo 7 destaca o estágio curricular supervisionado com um dos espaços fundamentais para se relacionar a teoria com a prática no processo de ensinoaprendizagem para o futuro professor da LE. Defende que a disciplina de estágio precisa garantir a construção de um campo de estágio onde o graduando tenha acesso ao contexto escolar e as práticas de ensino do professor regente, de maneira a vivenciar de maneira mais próxima a realidade que vai futuramente experienciar. Dessa forma, espera-se que a experiência na disciplina de estágio contribua efetivamente para a formação de um professor crítico-reflexivo, resultando em um ensino de LE de qualidade no Ensino Médio Brasileiro.

Pode-se também indicar o vol. I de Antonieta MEGALE (organizadora) com o prefácio de Ofélia García intitulada Educação Bilíngue no Brasil que dentro de um contexto bilíngue aborda teoricamente o ensino bilíngue nas escolas brasileiras, onde "a escola é livre para realizar uma diferente escolha" (MEGALE, 2019, p.69). "No México, onde a língua de instrução nas escolas é o Espanhol" (MEGALE, 2019, p.47). O espanhol e o inglês como língua estrangeira pode ser uma determinação na educação bilíngue: "qualquer sistema de educação escolar no qual, em dado momento e período, simultânea ou consecutivamente, a instrução é planejada e ministrada em pelo menos duas línguas". (MEGALE, 2019, p. 58). Ela procura seguir o viés da teorização da Educação através do ensino bilíngue.

A análise aqui apresentada é de suma importância para levar a uma reflexão sobre os aspectos primordiais para o desenvolvimento de um ensino de qualidade na área da Língua Espanhola, refutando a necessidade de práticas educacionais que considerem o sujeito com ser social, e faça do ensino da língua um aporte cultural, crítico e reflexivo. Para que isso ocorra de forma majoritária, destaca-se a importância de formações continuadas para os professores já atuantes da área, assim como a formação superior que priorize o processo aqui discorrido, para os professores em formação.

\section{REFERÊNCIAS}

MEGALE, A. (org.). Educação Bilíngue no Brasil. São Paulo: Fundação Santillana, 2019. v.I. 135p. 